\title{
Mother, Monster, Mrs, I: A Critical Evaluation of Gendered Naming Strategies in English Sentencing Remarks of Women Who Kill
}

\author{
Amanda Potts and Siobhan Weare
}

\begin{abstract}
In this article, we take a novel approach to analysing English sentencing remarks in cases of women who kill. We apply computational, quantitative, and qualitative methods from corpus linguistics to analyse recurrent patterns in a col- lection of English Crown Court sentencing remarks from 2012 to 2015, where a female defendant was convicted of a homicide offence. We detail the ways in which women who kill are referred to by judges in the sentencing remarks, providing frequency information on pronominal, nominative, and categorising naming strategies. In discussion of the various patterns of preference both across and within these categories (e.g. pronoun vs. nomination, title vs. surname vs. fore- name ? surname), we remark upon the identities constructed through the references provided. In so doing, we: (1) quantify the extent to which members of the judiciary invoke patriarchal values and gender stereotypes within their sentencing remarks to construct female defendants, and (2) identify particular identities and narratives that emerge within sentencing remarks for women who kill. We find that judges refer to women who kill in a number of ways that systematically create dichotomous nar- ratives of degraded victims or dehumanised monsters. We also identify marked absences in naming strategies, notably: physical identification normally associated with narrativization of women's experiences; and the first person pronoun, reflecting omissions of women's own voices and narratives of their lived experiences in the courtroom.
\end{abstract}


Keywords Corpus linguistics · Forensic linguistics · Language and law $\cdot$ Feminist legal methodology $\cdot$ Critical discourse analysis $\cdot$ Women offenders · Women who kill $\cdot$ Interdisiplinary approaches $\cdot$ Discourse analysis

\section{Introduction}

Statistically, women consistently make up a small minority of homicide offenders in England and Wales. Their low share of recorded involvement in homicides has historically resulted in women being excluded from scholarly consideration of this form of violent crime. However, a growing body of scholarship, particularly legal and criminological, has engaged with the experiences of women who kill (WWK) and their interactions with legal and criminal justice institutions (see, for example, $[36,50,53,54])$.

In this work, we add to the growing body of literature around WWK through tracing ideological positioning of the court by detailing the language of relatively powerful social actors (judges) as they discursively construct the identities of relatively powerless social actors (WWK) in legal documents (sentencing remarks). Though law is language and sentencing remarks are performative in nature, application of linguistic frameworks for social actor analysis in sentencing remarks is quite rare. Indeed, within the existing body of research on WWK, corpus linguistic methodologies (which provide both quantitative and qualitative approaches to analysis) have not yet been employed. This article is thus the production of an innovative methodological approach at the intersection between law, gender, and linguistics, drawing upon both qualitative and quantitative methods of analysis.

The research involves analyses of cases involving WWK in a custom-collected corpus of English Crown Court sentencing remarks, 2012-2015, where a female defendant was convicted of a homicide offence. We have chosen to specifically focus on cases involving WWK due to their relative rarity and the perceived deviance of these women in relation to understandings of appropriate femininity $[53,54]$. By focusing specifically on WWK - rather than taking, for example, a comparative approach involving cases of men who kill-we have been able to explore the judicial narratives surrounding these women, qua women. This, in turn, has allowed depth of understanding in relation to legal-discursive constructions of WWK which can help to develop understandings of the relationship between law and gender, particularly femininity. Thus, when analysing sentencing remarks, it is not the sentences themselves that we are interested in, but rather the naming strategies utilised to the end of (consciously or unconsciously) constructing identities by the judiciary. As such, in this article, we will be identifying and quantifying the ways in which judges invoke particular stereotypes and identities to position female defendants in gendered terms, while discussing specific supporting narratives that emerge within the sentencing remarks. We will conclude by 
exploring the implications of our analysis for future research, and for women who come into contact with the criminal justice system.

\subsection{Overview of Previous Legal Theory and Research}

There exists an extensive, and growing, body of literature surrounding the treatment of women within the criminal justice system as perpetrators of crime. Several seminal studies, including those by Allen [1], Worrall [55], and Edwards [17, 18], have highlighted the gendered response experienced by offending women when they engage with the criminal law and justice system. It has been argued that whilst the criminal law portrays itself as gender neutral (most notably through the so-called 'reasonable person' standard), the reality is that both the criminal law and justice system continues to be gendered masculine [9, 28]. Consequently, "female defendants are processed within the criminal justice system in accordance with the crimes which they committed and the extent to which the commission of the act and its nature deviates from appropriate feminine behaviour" [17: 213]. So-called 'appropriate femininity' is based on patriarchal understandings of what it is, and should be, to be a woman. For example, the notions that women are non-violent, passive, controlled by their hormones and emotions, and primarily understood in relation to their relationships with others, especially as wives and mothers (see, for example: [38, 54]).

Research has highlighted how these stereotypes around appropriate femininity have ramifications for the discursive constructions of WWK within socio-legal discourse. Indeed, the four broadly constructed socio-legal narratives that emerge in cases of WWK are those of the 'mad', 'sad', or 'bad' woman, or the woman as 'victim' [36, 50, 53, 54]. The particular narrative which emerges in individual cases of homicidal women depends on the extent to which these women are viewed as adhering to understandings of appropriate femininity (in the case of WWK as 'mad', 'sad', or 'victims'), or deviating from it (in the case of 'bad' women). As Worrall [55: 35] argues, "the female lawbreaker is offered the opportunity to neutralise the effects of her law-breaking by entering into a contract whereby she permits her life to be represented primarily in terms of its domestic, sexual and pathological dimensions"'. For those women who enter such a contract, it is the extent to which they (and their actions) can be understood in relation to appropriate femininity that dictates the discursively constructed narratives that emerge.

Very little of the existing research in relation to WWK has been at the legallinguistic interface and none of it has involved the application of corpus linguistic methods to such cases. The existing scholarship has largely examined the judicial language and discourses within appeal cases, particularly those involving filicidal women (see, for example: [54]) and battered WWK their abusive partners (see, for example: [10, 37]). This study casts a wider net, taking into account all cases of WWK in a given time period, to allow for an interdisciplinary, quantitatively-driven methodology. 


\subsection{Theoretical Overview of Linguistic Perspectives and Previous Research}

The absence of quantitative linguistic methodologies, such as corpus linguistic methods, in an analysis of the sentencing remarks of WWK is notable, particularly when considering that the law is enacted through language and sentencing remarks are discursive. Whilst such methods have been applied in other areas of the law, much of the focus has been on forensic approaches including authorship analysis (see, for instance: [12, 13]), comprehensibility (e.g. [49]), language during examination and cross-examination (e.g. [22]) or analysis of the 'voice' of Tribunals (e.g. [41]). Therefore, this article illustrates some of the latest work being undertaken at the legal-linguistic interface.

This research is undertaken in the spirit of critical discourse analysis, which holds Habermas's claim that "language is also a medium of domination and social force. It serves to legitimize relations of organized power" [19: 259], encode ideology, and to 'other' the powerless. Here, we are concerned with the relationship between the grammatical system of language and the social needs that language serves [20:142]. In the scenario of sentencing remarks, the judge has authorised power, both materially and metaphysically; he/she may choose (consciously or unconsciously) to foreground specific aspects of the accused's identity and/or actions in the retelling of the events [11, 15]. Sentencing remarks do not exist above or outside of sociocultural contextualisation; judges' language relies upon and incorporates ideologies (see, for instance: [24, 31, 40]) and 'fact' is framed for narrative coherence [27]. One way of tracing elements of narrative and ideological underpinnings is analysing the way that social actors are named and referred to. Here, we analyse references to WWK, who are relatively powerless in the discursive scenario; they are conceptualised and communicated as constituent categories of social situations, most often through the agency of others. Particularly in oral discourse, references to social actors serve various functions, such as: attracting attention; identifying the addressee; and maintaining and reinforcing the relationship between interlocutors [8, 29, 42]. Below, we detail the methods of searching and discussing notable social actor references.

\section{Description of Data and Methods}

\subsection{Data}

The data being analysed consists of a corpus of 48,361 words (tokens) made up of 17 sentencing remarks from England and Wales between 1st January 2012 and 30th November 2015 involving WWK. These were downloaded from the Courts and Tribunals Judiciary website [14].

It is worth noting that the 17 sentencing remarks which form the basis of our study do not reflect the total number of homicide cases involving female defendants over this time period. Indeed, statistics from the Office for National Statistics show 
that between April 2012 and March $2015,{ }^{1} 90$ women were convicted of homicide offences [39]. The primary reason for the discrepancy between these figures is simply that sentencing remarks are not made publicly available for most cases. Those remarks which are published online are usually only those associated with high-profile cases that have received substantial media attention, or involve cases that give guidance on legal issues [34]. Therefore, one arguable limitation of our data-set is its public nature. Indeed, it is possible to suggest that judges are potentially influenced by publicity when writing sentencing remarks in highprofile cases. The extent to which this occurs is impossible for us to measure. However, in many ways, this potential issue marks these sentencing remarks out as a particularly important source for analysis. By analysing publicly available sentencing remarks, we are examining those remarks that potentially have the most impact outside of the courtroom, at least on public discourse, as well as recognizing " judges ... [as] the most 'official' storytellers in contemporary human existence", [2: 501].

Due to the relative infrequency of female offending and the rarity of publication of sentencing remarks, the resulting data set is small by corpus linguistic standards. However, the corpus is opportunistic in that it contains all publicly available sentencing remarks for women convicted of homicide offences in England and Wales from a given time period, and is therefore as representative a sample as might conceivably be collected. The corpus reflects an interesting array of cases, containing single and multiple offenders, with offenders across a broad age range, and heterogeneity in victim profiles, as discussed below.

All sentencing remarks within our corpus came from homicide cases involving female defendants, either as sole defendants or as co-defendants with one or more co-offender. We classified cases involving co-defendants as being those where the female killer was tried, convicted, and sentenced alongside her co-offender(s). The co-defendants did not need to be found guilty of the same crime, but needed to have been involved in the same chain of events in the case. If women had killed alongside others, but were not tried, convicted or sentenced at the same time as their cooffenders, they were not classified as co-offending cases. Taking this approach, most of our cases (11 out of the 17) involved women as co-defendants, all of whom offended with male accomplices. ${ }^{2}$ The facts of the cases are very briefly summarised in Table 1 below to provide some context for discussions later in the paper. At the outset, it is worth noting that the naming strategy we use when referring to cases and discussing WWK is surname only. This approach has been taken to make identification of the relevant cases as easy as possible by reflecting the case names, for example $R v$ Bonser.

Only four of the cases within our dataset (Luczak, Lagwinowicz, Edwards and Philpott) were heard by female judges. This makes it difficult to consider the extent

\footnotetext{
${ }^{1}$ This is the time period for which data is available and that is closest to the time period we have used to collect the sentencing remarks.

${ }^{2}$ It is worth noting that this is a point of interest in and of itself as it prima facie supports some suggestions that when women co-offend it is typically with men and that when women commit particularly heinous crimes it is also typically as part of a co-offending relationship (see, for example, [7]).
} 
Table 1 Summary of cases contained in WWK corpus

\begin{tabular}{|c|c|c|c|c|}
\hline Offender name & Offence(s) & $\begin{array}{l}\text { Co- } \\
\text { offender(s) }\end{array}$ & Judge name & $\begin{array}{l}\text { Word } \\
\text { count }\end{array}$ \\
\hline $\begin{array}{l}\text { Ahmed, } \\
\text { Farzana }\end{array}$ & Murder of her daughter & Husband & $\begin{array}{l}\text { Mr Justice } \\
\text { Evans }\end{array}$ & 1950 \\
\hline $\begin{array}{l}\text { Bonser, } \\
\text { Hannah }\end{array}$ & Murder of a girl & - & $\begin{array}{r}\text { Mr Justice } \\
\text { Cranston }\end{array}$ & 1776 \\
\hline Chalk, Donna & Murder of homeless man & Three men & $\begin{array}{l}\text { Mr Justice } \\
\text { Walker }\end{array}$ & 2121 \\
\hline $\begin{array}{l}\text { Clarence, } \\
\text { Tania }\end{array}$ & $\begin{array}{l}\text { Manslaughter by reason of diminished } \\
\text { responsibility of her three children }\end{array}$ & - & $\begin{array}{c}\text { Mr Justice } \\
\text { Sweeney }\end{array}$ & 3351 \\
\hline $\begin{array}{l}\text { Dennehy, } \\
\text { Joanne }\end{array}$ & $\begin{array}{l}\text { Murder of three men, and attempted murder } \\
\text { of two others }\end{array}$ & Three men & $\begin{array}{l}\text { Mr Justice } \\
\text { Spencer }\end{array}$ & 12,140 \\
\hline $\begin{array}{l}\text { Edgington, } \\
\text { Nicola }\end{array}$ & $\begin{array}{l}\text { Murder of a woman and the attempted } \\
\text { murder of another }\end{array}$ & - & $\begin{array}{l}\text { His Honour } \\
\text { Judge Barker } \\
\text { QC }\end{array}$ & 2644 \\
\hline $\begin{array}{l}\text { Edwards, } \\
\text { Susan }\end{array}$ & Murder of her parents & Husband & $\begin{array}{l}\text { Mrs Justice } \\
\text { Thirlwall }\end{array}$ & 2481 \\
\hline Hoare, Shauna & $\begin{array}{l}\text { Manslaughter of male partner's step-sister } \\
\text { and other related offences }\end{array}$ & $\begin{array}{l}\text { Male } \\
\text { partner }\end{array}$ & $\begin{array}{l}\text { Mr Justice } \\
\text { Dingemans }\end{array}$ & 3267 \\
\hline $\begin{array}{l}\text { Hutton, } \\
\text { Amanda }\end{array}$ & $\begin{array}{l}\text { Gross negligence manslaughter of her son } \\
\text { and other offences related to maltreatment } \\
\text { of her children }\end{array}$ & Son & $\begin{array}{l}\text { His Honour } \\
\text { Judge Thomas } \\
\text { QX }\end{array}$ & 3022 \\
\hline $\begin{array}{l}\text { Kunene, } \\
\text { Virginia }\end{array}$ & Gross negligence manslaughter of her son & Husband & Mr Justice Singh & 2810 \\
\hline $\begin{array}{l}\text { Lagwinowicz, } \\
\text { Anna }\end{array}$ & $\begin{array}{l}\text { Murder of her male ex-partner's current } \\
\text { girlfriend }\end{array}$ & $\begin{array}{l}\text { Male ex- } \\
\text { partner } \\
\text { and uncle }\end{array}$ & $\begin{array}{l}\text { Mrs Justice } \\
\text { Sharp }\end{array}$ & 2088 \\
\hline $\begin{array}{l}\text { Luczak, } \\
\text { Magdelena }\end{array}$ & Murder of her son & $\begin{array}{l}\text { Male } \\
\text { partner }\end{array}$ & Mrs Justice Cox & 2934 \\
\hline Munshi, Fiaz & Unlawful killing of two children & - & $\begin{array}{l}\text { Mr Justice } \\
\text { Spencer }\end{array}$ & 3262 \\
\hline $\begin{array}{l}\text { Osoteku, } \\
\text { Victoria }\end{array}$ & Manslaughter of a boy & - & $\begin{array}{l}\text { His Honour } \\
\text { Judge } \\
\text { Christopher } \\
\text { Moss QC }\end{array}$ & 1311 \\
\hline $\begin{array}{l}\text { Philpott, } \\
\text { Mairead }\end{array}$ & Manslaughter of six of her children & $\begin{array}{l}\text { Husband } \\
\text { and } \\
\text { another } \\
\text { man }\end{array}$ & $\begin{array}{c}\text { Mrs Justice } \\
\text { Thirlwall }\end{array}$ & 4236 \\
\hline $\begin{array}{l}\text { Shuttleworth, } \\
\text { Rebecca }\end{array}$ & Murder of her son & $\begin{array}{l}\text { Male } \\
\text { partner }\end{array}$ & $\begin{array}{l}\text { Mr Justice } \\
\text { Spencer }\end{array}$ & 4040 \\
\hline $\begin{array}{l}\text { Smith, } \\
\text { Melanie }\end{array}$ & Murder of two adults and three children & - & $\begin{array}{l}\text { Mr Justice } \\
\text { Williams }\end{array}$ & 818 \\
\hline
\end{tabular}


to which judicial gender impacts upon language choice and naming conventions within these sentencing remarks. However, noting the fact that the vast majority of the judges are male is relevant for providing context for later analysis.

\subsection{Methodologies}

\subsubsection{Legal Methodology}

Underpinning the analysis undertaken in this article is a feminist legal methodology, centred around a critical interrogation of legal discourse, and reflecting 'feminist theoretical concerns about the way in which law constructs gender' [26: 7]. More precisely, we are interested in the extent to which gender stereotypes around appropriate femininity have influenced judicial narratives in cases of WWK. Reinforcing this feminist legal approach, we have made a conscious decision not to include analysis of cases of men who kill, nor to undertake substantive comparative analysis in those cases where women have co-offended with men. That is not to say that such analysis would not be useful in future research. However, we are clear that by considering sentencing remarks only in cases of WWK in this article, we are taking the feminist position that women, particularly female offenders, should not be considered the 'Other' ${ }^{3}$ [6: 6] as they often are within legal discourse. Rather than 'Othering' these actors, they are central to our analysis, thus helping us to understand the judicial narratives that emerge for these women qua women. Any approach incorporating comparisons to men who kill would arguably undermine this approach, as well as limiting the depth of analysis that has been produced here. A methodological point of note is that we use the terms woman/female interchangeably throughout the paper when referring to the WWK. As far as we are aware, these women are cisgender ${ }^{4}$ and thus, for the purposes of this paper, we treat them as such.

\subsubsection{Corpus Linguistic Methodology}

Generally speaking, “"[c]orpus linguistics is not a monolithic, consensually agreed set of methods and procedures", but is rather a heterogeneous field containing a group of methods for studying language [33: 1]. In this paper, we draw upon two main methods: frequency and concordance, which exemplify quantitative and qualitative approaches, respectively. Generating frequency lists is simply a way of determining which words occur in the corpus, and how many occurrences there are of each. Concordancing allows a researcher to search a corpus for a specific sequence (e.g. a word or a phrase) and output all examples of that sequence into an easily-readable format. We provide concordance lines throughout this paper, numbered, with search sequences in boldface, additional naming strategies (i.e. of other social actors) underlined, and further co-text salient for immediate discussion

\footnotetext{
${ }^{3}$ This idea of women as "Other" asserts that women are defined in opposition to men, by everything that men are not.

${ }^{4}$ That is to say that these women's gender identities "correspond" with the sex that they were assigned at birth.
} 
in italics. Remarks and the cases they are drawn from can be identified by the surname of the female offender in brackets at the end of any given concordance line.

To exploit both frequency and concordance data in this work, we have marked-up our data to enrich the sentencing remarks with primary pragmatic analysis. Naming strategies within the corpus are extremely diverse. For instance, "Hannah",

"Bonser", "she", "you", and "I" could all refer to the same social actor. In any given text, pronouns such as "her", "you", and "me" could refer to offenders, victims, or judges. To allow for a quantitative view over the language, we have incorporated XML mark-up, as recommended by Hardie [21]. Every reference to male and female offenders has been manually marked-up, opening up the opportunity for search-and-recall on a large number of search terms unrelated at the word level but near-synonymous at the pragmatic level. Each reference is marked-up for three features: gender, (grammatical) case, and naming convention. In this work, we make use of the 'gender' and 'name' tags ${ }^{5}$; these are described below.

Mark-up of naming convention:

- pro: Assigned for pronoun usage, i.e. I, your, her

- giv: Where some combination of title, (reduced) forename, and surname are used to refer to a social actor, e.g. Ms Hoare, Shauna

- cat: Rarely, when social actors are referenced not by pronoun or by name, but rather through some category of occupation or role, aligning with categorising naming strategies (van Leeuwen [52]), e.g. mother, killer

Mark-up of gender:

- f: Direct, individual references to female offenders

- Example: That morning, lactor gender = "f" case = "nom" name $=$ "giv"' Hannah Bonser Vactor[ had purchased two kitchen kni- ves at Boyes Store in Doncaster.

- m: References to male defendants, either singular or multiple co-offenders (all male)

- fm: References to female and male co-offenders in a single naming strategy

- fv: References to a female offender and a (female) victim in a single naming strategy; a very rare type (occurring 10 times total), mostly limited to the Philpott case (accounting for 9 instances).

Incorporating XML mark-up allows us to instantaneously search for naming strategies, cross-tabulated by gender (see Table 2 for frequencies) or naming convention (discussed in Sect. 3). This, in turn, affords greater flexibility in the application of frequency and concordance analysis.

\footnotetext{
${ }^{5}$ A critical evaluation of the grammatical 'case' of WWK forms the basis of our follow-up paper, currently in preparation.
} 
Table 2 Frequency of all naming strategies by gender

\begin{tabular}{lllllr}
\hline Gender of referent & F & M & FM & FV & Total \\
\hline Frequency & 1810 & 1195 & 431 & 10 & 3446 \\
\hline
\end{tabular}

\section{Analysis of Naming Strategies}

In the sections below, we detail all naming strategies for WWK in our corpus of sentencing remarks. For ease of discussion, the naming strategies are grouped under three categories: Pronominal (e.g. you, she), Nominative (e.g. Joanne Dennehy, Mrs Kunene), and Categorising (e.g. killer, mother). An overview of the usage of naming strategies falling under these categories, cross-tabulated by gender of offender and depicted by raw count and percentage of total references, can be found in Table 3 below.

The analysis is structured in such a way that the most frequent strategies (both by category and subcategory) are discussed first, with subsequent categories and subcategories appearing in order of descending frequency. As such, see Sect. 3.1 for Pronouns, Sect. 3.2 for Nomination, and Sect. 3.3 for Categorising naming strategies.

Table 3 Overview of reference category usage for female and male offenders, with raw frequency and percentage of overall naming strategies

\begin{tabular}{lclc}
\hline $\begin{array}{l}\text { Reference } \\
\text { category }\end{array}$ & $\begin{array}{l}\text { Frequency (female } \\
\text { offenders) }\end{array}$ & $\begin{array}{l}\text { Frequency (male co- } \\
\text { offenders) }\end{array}$ & $\begin{array}{l}\text { Log likelihood (female } \\
\text { to male) }\end{array}$ \\
\hline Pronominal & $1537(84.9 \%)$ & $921(77.1 \%)$ & $? 5.45$ \\
Nominative & $232(12.8 \%)$ & $239(20.0 \%)$ & -23.16 \\
Categorising & $39(2.2 \%)$ & $35(2.9 \%)$ & -1.72 \\
\hline
\end{tabular}


Table 4 Type, tokens, and frequencies of all pronominal references

\begin{tabular}{|c|c|c|}
\hline Reference type & Reference tokens (frequency) & Frequency ( $\%$ overall) \\
\hline Second-person pronoun & you (854), your (426), yourself (26), yours (2), $u$ & $1309(72.3 \%)$ \\
\hline Third-person pronoun & she (132), her (84), hers (1), herself (1) & $218(12.0 \%)$ \\
\hline First-person pronoun & $I(9), m y(1)$ & $10(0.6 \%)$ \\
\hline
\end{tabular}

\subsection{Pronominal References}

The most frequent method of referring to offenders across the sentencing remarks in our corpus is through pronouns (see Table 4 for indicative tokens and frequencies). English does not follow the $\mathrm{T}$ versus $\mathrm{V}$ form of other European languages, and thou and thee have fallen out of common usage, leading Hook to claim that "the reduction to a single form, you (sg. and pl.), means that, in modern standard English, the semantics of solidarity and power now lie elsewhere than the realm of pronoun usage" [25: 183]. However, as noted earlier, we consider each linguistic form to be a choice (conscious or not) on the part of the judge.

In this section, we analyse different patterns emerging in pronominal use, from most to least frequent (second-person, third-person, first-person). We make note of both majority/expected patterns (particularly in second-person pronoun usage) but also raise issues to do with minority/unexpected patterns (see our discussion on firstperson pronouns, below).

\subsubsection{Second-Person Pronouns}

Within the sentencing remarks, the most frequent pronominal naming strategy (and indeed, the most frequent reference type overall) used by the judiciary when referring to the female defendants is the second-person pronoun, i.e. you. This constitutes $72.3 \%$ of all references to WWK within the corpus (independently of references to women alongside male co-offenders). This result, whilst noted in and of itself, was not unexpected. Indeed, judges will typically directly address the defendant(s) when delivering sentencing remarks, summing up the evidence, commenting on mitigating and/or aggravating factors, and handing down the final sentence.

\subsubsection{Third-Person Pronouns}

The second most frequent pronominal naming strategy is the use of third person pronouns, i.e. she. This is an expected pattern in English narratives and therefore we must be wary of over-interpretation of the high frequency of this naming strategy within our corpus. Once a point of reference has been established explicitly, this information can be reused by substituting third person pronouns, thereby making the discourse less repetitive while still retaining cohesion. However, unlike first and 
second person pronouns, third person pronouns and all combinations of given name strategies are non-deictic. This means that when using naming strategies comprised of third person pronouns and given names, the judiciary create narratives that can be accessible not only to those sharing the same deixis but also to those who are not, i.e. people outside of the courtroom who are unrelated to the case, including journalists and members of the public. This is expected in relation to this set of sentencing remarks due to the high-profile nature of the cases. Indeed, it is likely that the judges involved knew that the sentencing remarks would be publicised beforehand and that they may have been influenced by this and so taken great care to create narratives cohesive to a range of audiences.

Whilst second and third person pronouns as pronominal naming strategies within the sentencing remarks are expected, the usage of first person pronouns is marked and discursively interesting.

\subsubsection{First-Person Pronouns}

In contrast to the significant usage of the second-person and third-person pronouns is the low frequency of first-person pronoun usage, ${ }^{6}$ i.e. I. Amongst the pronominal naming strategies, first-person pronouns are dramatically and markedly less frequent than other types. Only ten instances fall into this category, constituting $0.6 \%$ of total references to the women within our corpus. This may be explicable simply by reference to the nature of sentencing remarks, where the judge is directly addressing the defendant(s) and their actions, as well as recounting case facts. Indeed, this genre is typified by talking to and about defendants, re-framing and re-formulating their statements via indirect quotation; reflecting the judge's role as narrator. However, as Rackley [47: 53] argues, judges also act as persuaders through their story-telling, helping to create "a truth universally acknowledged." Therefore, it is "the way in which the judge tells the story, alongside the form and language of their opinion ..." [47: 46] that is important. We suggest that one consequence of an approach which largely rejects first person pronoun use is silencing of the voices and perspectives of 'others', i.e. offenders; in our case: female defendants.

The silencing of women's voices, especially those of female criminals, is well recognised within feminist legal and criminological scholarship (see, for example; $[4,5])$. Silencing is evident in the sentencing remarks analysed, with the ten instances of first person pronoun usage being confined to just three of the 17 cases that we analysed (Dennehy, Edgington, and Hoare). Where first-person pronoun usage appears, it is through direct quotation from the female defendants themselves. However, the way in which this direct quotation is utilised varies markedly across the three cases, with different impacts on identity construction for the women involved. Therefore, it is to an analysis of these three cases that we now turn.

First-person pronoun usage is most frequent in the case of Joanne Dennehy, with eight instances. Dennehy pled guilty to the murders of three men and the attempted

\footnotetext{
${ }^{6}$ Compared to third person pronouns, first person pronouns have a log likelihood value of -1710.96 . Compared to second person pronouns, first person pronouns have a log likelihood value of -235.28 . This represents significant underuse, with $p$ values well below 0.0001 .
} 
murder of two others, as well as three offences of preventing the lawful burial of her victims' bodies. In reviewing first-person pronouns in this case, it becomes apparent that Dennehy is not silenced and that her voice is indeed heard, at least to some extent. What is interesting is the way in which her voice is heard and the context within which it is used by the judge. Further analysis of the concordance lines demonstrates that Dennehy's voice is solely incorporated to strengthen the judge's narrative. Indeed, her voice is appropriated by the judge to reinforce his construction of her identity as a "bad" woman whose actions could not be reconciled within understandings both of femininity and of humanity.

1. I note that you told the psychiatrist that you killed to see how you would feel, "to see if I was as cold as I thought I was. Then it got moreish and I got a taste for it." [Dennehy]

Although Dennehy's voice $i$ s heard, it is in such a way that she further highlights the extreme deviance others perceive that she has exhibited. This is further reinforced by the fact that although Dennehy was diagnosed with numerous psychiatric and personality disorders, the judge did not afford her any mitigation [43: 17], and the narrative focus remained on the extreme deviance and depravity of her actions:

2. The only reason you can offer for the attempted murders is "drunken cruelty plain and simple, compelled by my lack of respect for human life". As I have already made clear, I reject your protestations of remorse for these attempted murders. [Dennehy]

First-person pronoun usage also features in Nicola Edgington's sentencing remarks. Edgington was found guilty of the murder of Sally Hodkin and attempted murder of Kerry Clark. She left a closed psychiatric unit where she had asked to be seen after indicating that she was dangerous and having a breakdown. She then stole a knife from a butcher's shop and used it to attack Hodkin and Clark. The firstperson pronoun only appears twice in her sentencing remarks, both in the same sentence, and both in relation to Edgington's experience of being ignored by health care professionals when attempting to describe her deteriorating mental health prior to the attacks:

3. You said later that 'they were just tapping keyboards, I told them I was going to hurt someone, this all their fault.' [Edgington]

Whilst this may simply be verbatim of accepted evidence, it appears, prima facie, that her perspective is therefore being included by the judge. Her voice is clearly not being directly silenced in the way that other women are where first-person pronoun use is excluded, and it is arguably not appropriated and re-narrativised in the same way that Dennehy's is. Rather, we suggest that what is occurring is a subtler form of indirect or hidden silencing. This can be illustrated by drawing upon Ballinger's [4] and Barlow's [5] work on the silencing of offending women. They note that potential for the development of new subject positions for female offenders can be 
closed by legal discourse, for example by only partially presenting their perspectives, i.e. 'hidden' silencing or 'muting' of the voice.

The final case where first-person pronouns appear is that of Shauna Hoare. Hoare was convicted of the manslaughter of 16-year-old Becky Watts, the step-sister of her co-offender, Nathan Matthews (who was found guilty of murder). Hoare was also found guilty of conspiracy to kidnap Becky, perverting the course of justice, preventing the unlawful burial of Becky and the possession of two stun guns. The first-person pronoun usage here appears in a different context. Whereas in Dennehy and Edgington, first person pronoun usage features in relation to oral testimony given by the two women, in Hoare, it constitutes part of written evidence in the form of a text message sent by Hoare to Matthews:

4. He [Nathan Matthews] had started exchanging text messages with Shauna Hoare in which they had discussed kidnapping pretty teenage school girls for sex ("fuck u bring me bk 2 pretty school girls" and "lol yhh i ll just kidnap them from school"). [...] The false suggestion given by both of them during trial, namely that these texts were just banter or pandering to tastes, shows how much their understanding of where proper boundaries of conduct began and ended had become corrupted and warped. [Hoare]

Whilst again this may be an example of the judge repeating evidence verbatim, the way in which it is used and the narrative built around it helps to construct a picture of the co-defendants' relationship. By preceding the text message from Hoare with that sent by Matthews which is both abusive ("fuck u'), and includes a degrading command ("bring me bk 2 pretty school girls"), the power imbalance between the two defendants is highlighted. This is reinforced later in the remarks where the judge explicitly notes that Hoare's “involvement in these offences was very much a product of the nature of the relationship with Nathan Matthews" [46: para 29]. However, it is clear the judge is attaching significant culpability to Hoare for her involvement in the crimes by highlighting deviance from " proper boundaries of conduct"' [46: para 15]. Therefore, the inclusion of Hoare's voice serves to both position her within a recognisably 'feminine' role (subservient to a male partner), while simultaneously contributing to a narrative of deviance and 'othering'.

Interestingly, even where first person pronoun use is indicative of the inclusion of WWK's own voices, it is extremely rarely indicative of the inclusion of WWK's own narratives. As such, the power of these women's perspectives is diminished or denied, and they remain in the traditionally feminine position of passivity and silence.

\subsection{Nomination}

Whilst the use of pronouns is far more frequent than other naming strategies, our analysis also highlights that WWK are referred to (or nominated) by several combinations of given names in sentencing remarks. As noted in the preceding analysis, in and of itself this fact is unsurprising due to the non-deictic nature of these naming strategies. However, as our subsequent analysis will demonstrate, the 


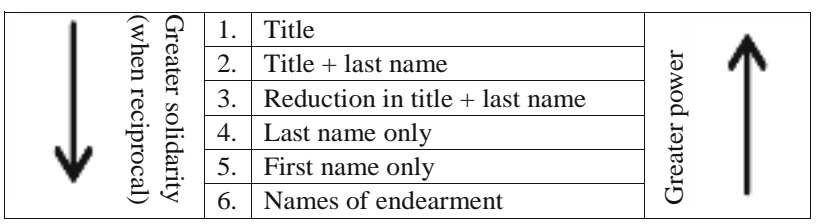

Table 6 Type, tokens, and frequencies of all given name references

\begin{tabular}{lcc}
\hline Reference type & Reference tokens (frequency) & $\begin{array}{c}\text { Frequency } \\
\text { (\% overall) }\end{array}$ \\
\hline Forename ? surname Joanne Dennehy (62), Shauna Hoare (29), Hannah Bonser (21), & $183(10.1 \%)$ \\
& Rebecca Shuttleworth (13), Donna Chalk (12), Susan Edwards \\
& $(12)$, Mairead Philpott (11), Magdelena Luczak (8), Amanda \\
& Hutton (6), Anna Lagwinowicz (3), Farzana Ahmed (3), Fiaz \\
& Munshi (2), Tania Clarence (1) & $24(1.3 \%)$ \\
Title ? surname & Mrs Kunene (15), Ms Hoare (9) & $21(1.2 \%)$ \\
Surname & Lagwinowicz (21) & $4(0.2 \%)$ \\
Forename & Mairead (3), Rebecca (1) &
\end{tabular}

power and solidarity relationships intimated by certain naming strategies provide some interesting and novel insights into the gendered identity constructions of the female defendants under consideration.

Leech [29: 110-111] provides a list of potential semantic categories of nomination, in order from most intimate to most distant:

1. Endearments: e.g. darling

2. Family terms: e.g. mummy

3. Familiarisers: e.g. mate

4. Familiarised first names: e.g. Becky

5. First names in full: e.g. Rebecca

6. Title and surname: e.g. Mrs Johns

7. Honorifics: e.g. Madam

Choice of name serves an important social-marking function that speakers of European languages may recognise with the $\mathrm{T}$ versus $\mathrm{V}$ pronouns. For instance, first-name address indicates a sense of equality of common closeness, whereas title ? surname marks distant, respectful relationships between interlocutors [32: 154]. So, in addition to social proximity, power may also be embedded in naming strategies. Hook [25] provides a ranking (adapted in Table 5) to suggest the hierarchy of naming in English.

In this section, we analyse the use of given name strategies to consider the role that these play in constructing identities, particularly gendered ones, for WWK. 
Given name strategies comprise approximately $13 \%$ of all references to this class of social actors in the corpus of sentencing remarks; in Table 6, we provide an overview of reference tokens and frequencies.

As in Sect. 3.1, our discussion progresses from the most frequent naming strategy (forename? surname) to the most uncommon naming strategy (forename only). Illustrative examples from the data and additional information from the cases appear within the discussion to support our analysis.

\subsubsection{Forename? Surname}

The preferred given name usage is clearly forename ? surname, with a frequency of 183, and the majority of WWK (13 out of 17) appearing in the corpus in this manner (see Table 6). On the cline of formality/solidarity, forename ? surname is neutrally positioned. Even unconsciously, this may account for the overwhelming preference of judges for this naming strategy. The forename ? surname strategy is explicit in its reference, often appears in the vocative case (e.g. in sentencing remarks containing more than one offender, where it is frequently used), and does not obviously make any attempt at distancing or solidarity.

Notably, for the majority of WWK (Dennehy, Bonser, Chalk, Edwards, Luczak, Hutton, Ahmed, Munshi, and Clarence), forename? surname is the only given name strategy assigned to them. An explanation for this may be that it is a stylistic preference of the judges handing down the sentences, or that it reflects an approach proposed during their judicial training. There may be another possible explanation, though. The majority of these women (Dennehy, Bonser, Chalk, Edwards, Luczak, and Ahmed) were found guilty of murder (rather than another 'lesser' homicide offence). Further, whilst Hutton was not convicted of murder but unlawful act manslaughter, the judge explicitly noted in sentencing that the case had "to be regarded as a bad a case of unlawful killing of a child by a parent as it is possible to imagine", [44: 5]. Moreover, whilst Munshi and Clarence were also not convicted of murder but unlawful killing and manslaughter by reason of diminished responsibility respectively, both of these women killed multiple children. Therefore, the formality of referring to these women by forename? surname may reflect the seriousness of their offences. We revisit other naming strategies which may key severity below.

\subsubsection{Title? Surname}

Only two sentencing remarks in our corpus include the use of title ? surname as a nomination strategy: Mrs Kunene (14) and Ms Hoare (9). As noted in Table 6 above, Hoare is most frequently nominated as forename? surname (29 instances), but has nine instances of title? surname. The mixed nomination strategies in this case are, we believe, most likely a reflection of the judge's sentencing style and thus we have decided to exclude consideration of the title? surname nominations here as we are wary of over-interpretation. However, the use of title ? surname in the case of Kunene is marked and thus discursively interesting. Indeed, in this case all given name references to Virginia Kunene (and her husband Nkosiyapha Kunene) 
are in the form of title? surname. This is the only case in which this occurs and thus further consideration will be given to this below.

Kunene was married, and she and her husband were the parents of Ndingeko Kunene, who died less than 6 months after birth from florid rickets resulting from a severe vitamin D deficiency. Ndingeko Kunene had medical problems and fluctuating health from birth, but because of religious beliefs as strict Seventh Day Adventists, Virginia Kunene (and her husband) did not seek medical assistance when he became unwell. Therefore, on the day he died, although realising that he was very unwell and at risk of death, Kunene continued not to seek medical assistance. She pled guilty to gross negligence manslaughter "only on the basis of the omission to call for medical attention" [45: 4]. (Her husband also pled guilty to gross negligence manslaughter).

There are two potential reasons we suggest for the sole use of title ? surname nomination in this case. The first is that this is simply the judge's stylistic preference; indeed, the fact that the judge uses the same nomination for the male offender in this case could well support this (see concordance line 5 below). Therefore, we are continually on guard for over-interpretation. However, in viewing concordance lines where Mrs Kunene appears, a second possibility occurs: that Kunene's actions are perceived as capable of recuperation within understandings of 'appropriate femininity', particularly centred around passivity, good character, and membership of a (dedicated) heterosexual marriage. Indeed, the good character of Kunene, as well as her (heterosexual) marital status and 'dedication' to her relationship indicated therein, are all explicitly noted as mitigating features in the case:

5. It is accepted on all sides that the following are mitigating features: (1) The good character of each Defendant. Mr Kunene is now 36 years of age and Mrs Kunene is 32 . They are a dedicated and humble couple. [Kunene]

Whilst previous good character is recognised as a mitigating factor within sentencing guidelines when considering the seriousness of the offence [51], it is once again the way in which this is presented by the judge that we are concerned with. The context provided around her son's death focuses upon her submission and deference to her husband, whose religious views were "very extreme", [45: 2-3]. It was also explicitly noted that Kunene did wish to seek medical attention for her son but was advised by her husband "that it would be a sin in the eyes of God to call for medical assistance as he had made a vow that he would await guidance from God before doing so" [45: 4]. Her "religious convictions were a significant factor in deference to her husband's view ... and her omission to call for medical attention", [45: 4]. A focus on this context helps to construct Kunene as a woman who can be rehabilitated within patriarchal understandings of femininity, which require women to be passive, non-aggressive, and often defer to the view of their husbands. This is further reinforced by the fact that her actions in relation to her son's death were peculiarly feminine; Kunene did not actively kill her son through aggressive means, but acted passively in failing to get medical attention for him, resulting in his death. Thus, whilst she transgressed understandings of femininity by being involved in the death of her son, her passivity in this, and her seeming adherence to patriarchal constructions of femininity in every other aspect of her life, meant that she could be 
"represented as more recognisably feminine"' [50: 8]. As such, we suggest that the sole use of title ? surname nomination in this case reflects a degree of 'respect' and distance being accorded to her by the judge, perhaps because of her adherence otherwise to expectations of women within appropriate femininity.

\subsubsection{Surname Only}

The only WWK in the corpus to be referred to by surname only is Lagwinowicz (freq. 19). Anna Lagwinowicz, alongside her ex-boyfriend and another male defendant, killed her boyfriend's current partner in order to claim her life insurance policy. The murder was premeditated, with Lagwinowicz contacting her ex-boyfriend on hundreds of occasions to plan, as well as put together a trail of false evidence. Once they had conducted the murder, they disposed of the body. It must be noted that the judge in this case refers to all of the defendants (two men and one woman) by surname only, save for two vocative instances of forename? surname. This is in contrast to nomination of the victim, who is most often referred to as forename only:

6. On Catherine's graduation day in 2011, Lagwinowicz sent a text to Catherine, telling her Nowak was in her bed, as he was, though he claimed he had been lured there by Lagwinowicz and drugged. [Lagwinowicz]

Again, while we are wary of over interpreting the stylistic preference of a particular judge, we note that this combination of nomination distances listeners/readers from the defendants while creating a sense of social proximity to the victim. By creating greater solidarity with - and humanisation of - the victim, the judge reinforces the heinous nature of the crime that took place. Moreover, the use of surname only indicates decreased power encoded into the text [25] and has the additional effect of obscuring the gender of the actor. Without the inclusion of the recognisable feminine forename Anna or of a gendered title (which would additionally imbue power), the social actor Lagwinowicz is discursively stripped of gender. This is an interesting approach to take, not least because gender can be so central to an individual's identity. Thus, by removing references to her gender through a surname only naming strategy, the heinousness of Lagwinowicz's actions are centralised and there is no attempt to explain or justify her actions in relation to her identity as a woman. Indeed, whilst Lagwinowicz is referred to as 'girlfriend' once within the sentencing remarks, this is an identifying naming strategy in the context of her within a heterosexual relationship (see Sect. 3.3.1 below), rather than a focus on her gender. In this way, the challenge that her actions could pose to patriarchal constructions of appropriate femininity is nullified through a discursive construction of her as genderless and thus a non-woman [53, 54].

\subsubsection{Forename Only}

Forename only is the least frequent nomination in the corpus. Only two female defendants are referred to by forename only: Mairead [Philpott] (3) and Rebecca [Shuttleworth] (1). 
Philpott was convicted of the manslaughter of six of her children. With her husband and another male friend she set fire to their house whilst her children slept upstairs in an effort to frame her husband's ex-partner and to remove her children from her care. When Philpott is referred to by forename only it appears that this is to illustrate her subordinate position in the family, particularly in relation to her husband.

7. Apparently you expected Mairead to remain in the house with the children just as before. [Philpott]

8. You then met Lisa Willis as I have described. Mairead agreed to have her in the house. She told the court she was hurt. Of course she was. You did not care. You controlled and manipulated those women... [Philpott]

9. You made sure that Mairead "stuck to the story". Checking with her at every opportunity that she wasn't going to stray, as you put it. [Philpott]

Therefore, these instances of referring to Philpott by forename only may be an attempt by the judge to acknowledge the context within which she acted in participating in the death of her children, and to do so in a way that demonstrates some compassion or understanding. This indicates her dual role as offender (killer of her children) and victim (of her co-offender husband). Indeed, within our corpus, (as has been noted in preceding analysis), it is the female defendant's victims who are typically referred to by forename only. This naming strategy used in this way clearly constructs offenders as powerless [25] and with a high level of solidarity [29].

A different use of forename as a naming strategy is taken in the case of Shuttleworth. She was convicted of murdering her young son, Keanu, after seriously assaulting him and subsequently failing to arrange appropriate medical attention to treat his life-threatening injuries. In the sentencing remark, she is far more frequently referred to by forename surname, and only one instance of forename only appears:

10. But as you [Luke Southerton] told your friend Wayne Collins, Rebecca and Keanu came as a package. [Shuttleworth]

This may be another example of the judge repeating accepted evidence verbatim, with the use of forename only here being an indirect quote in her partner's (Luke Southerton's) intimate voice [29]. By using this quote it reflects how Luke would refer to her: with high solidarity and low power imbalance. It is also possible that the singular occurrence of forename only may be for greater symmetry with "Keanu' (her son and victim) as they are being discussed as part of a family unit.

\subsection{Categorising Naming Strategies}

The main subject of this paper so far has been nomination, or reference to social actors' unique identities in discourse. According to van Leeuwen [52: 42-45], social actors may also be categorised, or represented according to what they do or who they are. There are three forms of categorisation: 
Table 7 Frequency of identifying, functionalising, appraising and differentiating naming strategies

\begin{tabular}{|c|c|c|c|}
\hline $\begin{array}{l}\text { Reference } \\
\text { category }\end{array}$ & Subcategory & Reference tokens (frequency) & Freq. \\
\hline \multirow[t]{3}{*}{ Identification } & Relational & $\begin{array}{l}\text { mother (10), parent (5), wife (4), girlfriend (3), Keanu's } \\
\text { mother (1) }\end{array}$ & 23 \\
\hline & Classification & woman (3), very young woman (1), girls (1), mad woman (1) & 6 \\
\hline & Physical & - & \\
\hline Functionalisation & & $\begin{array}{l}\text { killer }(1), \text { group of killers }(1), \text { serial killer }(1), \text { triple } \\
\text { murderer }(1), \text { suspect }(1), \text { defendant }(1)\end{array}$ & 6 \\
\hline Appraisement & & monster (2), skivvy (1), slave (1) & 4 \\
\hline Differentiation & & $\begin{array}{l}\text { anyone (1), any normal parent (1), individual in decent } \\
\text { society (1) }\end{array}$ & 3 \\
\hline
\end{tabular}

\section{- Identification}

- Classification: representation based on membership of certain major social categories such as gender, age, wealth, e.g. teenager

- Relational identification: representation based on relationships, such as personal, kinship, or work relations, e.g. mother

- Physical identification: representation based on physical characteristics, e.g. blonde

- Functionalisation: references in terms of an activity, such as a role or occupation, e.g. killer

- Appraisement: interpersonal terms, whereby social actors are "referred to in terms which evaluate them as good or bad, loved or hated, admired or pitied" (van Leeuwen [52:45]).

The final group of naming strategies under discussion deals with these 'categorising' naming strategies: identifying (reference through social category membership, relationships, or physical characteristics), functionalising (reference to offenders in terms of an activity, role, or occupation), and appraising (reference through explicitly evaluative terms). As we have read through and manually marked-up the corpus, we have had the opportunity to identify additional, auxiliary methods of identity construction through differentiation, or differentiating individual social actors from similar actors or groups, creating a difference between 'us' and 'them' (van Leeuwen [52: 40]). We will discuss three instances of differentiation, where women are referred to by what they are not. Frequency counts and reference tokens under these categories can be found in Table 7 above.

\subsubsection{Identifying Naming Strategies}

A number of interesting traces of ideological positioning are evident when analysing the most frequent pattern: Identification. These fall under two populated subtypes 
(Relational and Classification) and one unpopulated subtype (Physical). All subcategories are discussed below.

\section{Identification: Relational}

This subcategory is populated with relational naming strategies such as mother (frequency: 10), parent (5), wife (4), and girlfriend (3). From this, it is clear that in the cases analysed, WWK are commonly categorised and identified through their position within the family; this keys socio-cultural understandings of 'appropriate femininity' within the boundaries of the mother/parent or wife/girlfriend tropes.

Of the Relational Identification strategies, those associated with motherhood

(mother, parent) appear most frequently. This is likely because seven of the cases we analysed involved women killing their children (see Table 1). Within sentencing remarks, one would expect to see the judge refer to the roles and relationships between the offender(s) and victim(s), especially if "these roles and identities were of primary relevance to the killing' [50: 209]. This is evident in all the sentencing remarks where victims were known to their killers, not only those involving filicide.

It is apparent in some of the remarks that the context within which these Relational

naming strategies are used highlights these women's extreme deviance from

'acceptable' performances of mothering, i.e. those outlined within the so-called 'motherhood mandate'. The mandate reflects the societal definition of "women as caretakers of children'" [48: 102], requiring women not only to want children, but when they have them, to subordinate their own personal needs and desires for those of their child(ren) [48: 102]. In the case of Hutton, the judge used the relational identifying parent to highlight some of the expectations associated with motherhood;

11. Your use of alcohol over the years gives a real insight into you as a parent. Namely [...] that you placed your own selfish addiction to drink well before your responsibilities to your many children. [Hutton]

The deviance of mothers within the sentencing remarks is further emphasised through juxtaposition of the 'norm' and the 'deviant' in Relational Identification. For instance, Clarence is "caring and patient" but "overwhelmed", ultimately leading to a prolonged depressive state, culminating in the killing of her children (line 12, below).

12. ...your GP noted that you were a caring and patient mother - albeit overwhelmed by the number of medical appointments that you had to attend... [Clarence]

The dichotomy of 'good' and 'bad' women and 'good' and 'bad' mothers is also evident through the use of Differentiation, for example in the case of Shuttleworth.

13. There was only one reason why you, Keanu's mother, did not summon medical help or take him to hospital that weekend, as any normal parent would have done. It was your fear that this time the injuries inflicted upon him could never be explained away. [Shuttleworth] 
Positioning Shuttleworth in this way forcefully condemns her behaviour through an explicit recognition that her fear of punishment in the criminal justice system was placed above the wellbeing of her child (the latter of which would have been the expected behaviour of "any normal parent").

In the same vein, the 'bad' mother construct is reinforced by the stressing of Relational Identification through repetitious constructions:

14. His was a lingering death over many hours following a brutal assault by his own mother. [Shuttleworth]

15. What was it that brought you two-her parents, the people who had given her life - to the point of killing her? [Ahmed]

Once the mother-child relationship is established, the motherhood mandate of immediate and unwavering love and provision of care is contrasted with the actuality of violence and death. In this way, repetitious constructions highlight these women as 'bad' mothers; women "whose neglectful, abusive, reckless, or murderous behaviours ... destroy[ed] [their] children" [3: 1019]. Thus, we can see that through their language choices, some of the judges maintain the figure of the "'bad' or 'unfit' mother [which] has [long] been a powerful figure in Western law" [3: 1019]. They also maintain the dichotomy between "'good' and 'bad' mothers [which] serves as a means of patrolling, controlling and reinforcing the boundaries of behaviour considered 'appropriate' for ALL women and mothers" [35: 217].

Though Relational Identification is most frequently recognised through motherhood, several additional naming strategies identify WWK through their romantic relationships with men. None of the women within our corpus were convicted in relation to the death of their partner and therefore it is not in this context that the identifiers 'wife' and 'girlfriend' emerge. Rather, when these relational identifiers are used, they are in the context of women who co-offended with romantic partners. Whilst the use of these relational naming strategies themselves is perhaps expected given these contexts, what is of interest is that only gendered relational identifiers are used (wife, girlfriend), whereas gender neutral options such as 'spouse' or 'partner' are rejected. Moreover, the way in which these gendered terms are used within the sentencing remarks is noteworthy and worthy of further exploration.

The Relational Identification wife is particularly interesting; whilst it places the women squarely within a heteronormative frame of (good) social standing, this is also traditionally understood to be a position of subordination within a patriarchal society. It is this position of subordination within which wife is most frequently invoked by the judges in their sentencing remarks. In line 16, we see how Mrs Kunene's decision making is overridden by her husband, who advises against medical intervention, citing religious reasons. Concordance line 17 also indicates the other ways in which women are disempowered within the frame of marriagethrough physical control and violence at the hands of their partners. 
16. Mr Kunene accepts that he advised his wife that it would be a sin in the eyes of God to call for medical assistance as he had made a vow that he would await guidance from God before doing so. [Kunene]

17. You subjected your wife to physical violence throughout your relationship. She never reported anything to the police. She was too afraid to do so. [Philpott]

Using 'wife' to highlight the subordination of these women within their cooffending relationships emphasises their disempowerment without specifically labelling them as 'victims', which would have disempowered them completely. Consequently, the women can still have varying degrees of culpability attached to them - at the discretion of the judge — whilst simultaneously some explanation can be offered for their actions (i.e. involvement in a co-offending relationship with their husband/partner). In turn, the challenge posed by these women to understandings of 'appropriate femininity' is limited by recuperating their actions within the context of a relationship within which power still swings towards the man. Indeed, the gendered identities created for these women as wives reinforces the notion that women should be dependent on men, broadly affirming that women lack independence and status.

While exploring title ? surname nomination (at 3.2.2), we discussed social indexing of (heteronormative) marital status as positive, with nominations encoding 'respect' and distance. Above, we see that construction of WWK as wives reveals a more nuanced understanding of the actual functioning of relationships in a patriarchal society. To that end, the sentencing remarks demonstrate that the naming strategy of girlfriend can be doubly disempowering: girlfriends are unmarried (and therefore lack social status), but are still subordinates within personal relationships. In line 18, we see that Nowak (Lagwinowicz's male co-offender) is described as leaving his then girlfriend Lagwinowicz to begin a relationship with Catherine Wells-Burr, their eventual victim. So, while wife (or Mrs) has the positive effect of enhanced social status, girlfriend lacks both status and permanence, appearing in constructions where women are further subordinated and more open to abandonment. ${ }^{7}$

18. Catherine worked on the production line at Numatics in her university vacation. It was there, in 2010, that she met Nowak; their relationship began, and he left his then girlfriend, Lagwinowicz. I suspect even then, Catherine's family had their reservations. By the time of her death, Jayne, with a mother's instinct certainly did. [Lagwinowicz]

\section{Identification: Classification}

Further naming strategies of Identification include six under Classification. Classifying naming strategies underscore the salience of gender and age in these sentencing remarks; woman (3), very young woman (1), girls (1), and mad woman

\footnotetext{
${ }^{7}$ It is noteworthy that in line 18 , offenders are referred to by surname only, whereas the victim and her mother are referred to by first name, further underscoring our previous findings in Sect. 3.2, where 'norm' identities are constructed as socially close and feminised with first name use, whereas 'deviant' identities are distanced through surname use, with femininity erased.
} 
(1) appear relatively infrequently and serve to categorise WWK more widely into (gendered, aged, moralistic) roles within society. While naming strategies from this category may seem more neutral than those listed under Functionalisation, these are used to evidence deviation from expected roles and feminine behaviours. In line 19, the judge expresses the unlikelihood that Smith would commit such a crime, given her gender, age, motherhood, and lack of previous convictions:

19. At first blush, it seemed unlikely that a woman of your age, a mother of five children with no previous convictions should even contemplate setting fire to a house let alone a house with people in it. [Smith]

These naming strategies, then, can indicate a transformation in progress. Participation in the legal system as a defendant is, in itself, othering, and further contrasts may be set up through naming strategies. WWK are described as previously having 'in-group' qualities, which then transition to 'out-group' qualities (such as lack of employment or friends) in line 20 .

20. Susan Edwards, you had worked as a very young woman but gave up your post in the 1980s and did not work after that. You had no friends and did not enjoy meeting new people. [Edwards]

The classifying naming strategy of 'mad' appears in the case of Dennehy, in the voice of one of her victims:

21. John Chapman described you to another tenant, Toni Ann Roberts as "the mad woman". [Dennehy]

The inclusion of this term of Identification is interesting on multiple levels, not least because Dennehy pleaded guilty to the murders she was accused of and did not raise a defence such as diminished responsibility (which would invoke discourses of 'madness'). Firstly, this form of Identification, whilst being extremely othering due to the associated stigma of mental illness [23], provides an 'appropriately feminine' rationale for her murders. That is to say, the 'mad' identity fits well with certain ideas about women and femininity, namely that "women ... are determined by their biology and their physiology. Their hormones, their reproductive role, inexorably determine their emotionality, unreliability, childishness, deviousness etc. These facts lead to female crime" [23: 112]. In Dennehy, the inclusion of the folk term mad woman (in the victim's voice) differs from the judge's inclusion of psychiatrist reports, which describe Dennehy as being diagnosed with a "psychopathic disorder", "severe emotionally unstable personality disorder", "antisocial personality disorder", and "paraphilia sadomasochism”. These formal, specific, and medicalised terms reflect a range of mental disorders, the particular effects of which may not be readily understood by the text's audience. Therefore, the judge takes a departure in including the less specific mad woman, which indexes cultural (mis)understandings about and taboos around mental health disorders [23].

Despite the inclusion of this identifying term, a second point of interest arises, namely that this is not the dominant naming strategy that emerges in Dennehy's case. As we will discuss below (at 3.3.2), functionalising naming strategies that 
emphasise Dennehy's extreme deviance are most frequently invoked by the judge. Thus, we suggest that the inclusion of the 'mad' classifier through the voice of one of her victims, alongside a detailed acknowledgment of the evidence presented by her psychiatrist (despite no plea of diminished responsibility), is done to demonstrate how Dennehy may be viewed by others.

\section{Identification: Physical}

Physical identification (e.g. 'beauty') does not appear in the corpus at all. Its absence is noteworthy because of its usual importance; physical appearance plays a powerful role in cultural definitions of femininity [30:34] and this is reflected in public discourse. This is particularly true for WWK, with media reporting emphasising these women's appearances [16]. Whilst we have seen that discursive constructions of femininity are both relevant and important to the judiciary (either consciously or unconsciously), this particular element of femininity appears not to be. One obvious explanation for this is that the physical appearances of WWK have very little to do with the homicides they have been convicted of (contrary to what media discourse would suggest). Another is that commenting on and identifying women in relation to their physical appearance may be perceived as overtly sexist or gendered, and thus a conscious decision to avoid such an approach may have been made. Whatever the explanation, the exclusion of physical identification within the sentencing remarks highlights one clear difference in the way that WWK are constructed by the judiciary versus the media.

\subsubsection{Functionalising Naming Strategies}

Functionalising naming strategies are found only six times in the corpus. No doubt largely due to our data type, these all construct WWK in terms of their 'legal role': triple murderer (1), suspect (1), serial killer (1), killer (1), group of killers (1), defendant (1). Arguably, this is the most expected naming strategy for WWK in sentencing remarks, as their most salient identity within the discourse of sentencing remarks is related to functionalisation of their role within the legal process. However, what is of interest here is that only two instances use distinctively 'legal' terminology—suspect and defendant.

22. Then, on 23rd September 1997, you were arrested and interviewed as a suspect. You told the police the same lies. [Munshi]

23. Coming the other way on the same path, was the defendant, Hannah Bonser. [Bonser]

The use of 'folk' terms such as killer appear more frequently, emphasising the deviance of the referents in a way that 'legal' terminology does not. Indeed, the use of killer as a Functionalising naming strategy in the cases of Osoteku and Hutton contributes to a compounded image of these women as particularly violent and odious.

24. You joined the group of killers who set upon Sofyen Belamoudden as he lay helpless and defenceless upon the floor of the ticket hall, having pursued him 
down the stairs as he fell, in the sight of those many horrified onlookers who had been going about their lawful business at the height, as I have said, of the rush hour. [Osoteku]

25. Preventing the proper burial of Hamzah over a period of almost 2 years following him being starved to death by you and you being afraid to report his death because of your fear of being found out as his killer. [Hutton]

The term killer also appears, alongside that of murderer, in the case of Dennehy. However here, both terms are quantified in a way that they are not in other cases:

26. You are a cruel, calculating, selfish, and manipulative serial killer. [Dennehy]

27. They did not involve any violence but they demonstrate a willingness to assist a triple murderer to evade justice. [Dennehy]

The quantification strategies used by the judge do not only serve the function of highlighting case facts, but also further emphasise Dennehy's depravity and her discursive construction as a 'bad' woman. In line 26 we see serial killer used to emphasise Dennehy's deviance, both in the context of her crime and her demeanour. In line 27, Dennehy is depicted as the leading actor in the murders, assuming a dominant role over her male co-offenders. She is regarded as the 'mastermind' and thus as a "dangerous, unsettling figure" [50: 40].

\subsubsection{Appraising Naming Strategies}

Four additional instances of Appraisement complete the set of Determining naming strategies: slave (1), skivvy (1), and monster (2). These only appear in two cases within the corpus: Philpott (2) and Dennehy (2).

Two of the naming strategies in this group (slave and skivvy) appear in a single clause in the Philpott case:

28. I accept that he treated you as a skivvy or a slave, and you were prepared to put up with that. As became clear during the trial, you were prepared to go to any lengths, however humiliating, to keep him happy. At an early stage of the trial, it appeared that you were entirely downtrodden by Michael Philpott to the extent that it appeared that you felt you had no choice but to do whatever he wanted in whatever way he wanted in any aspect of your lives together. [Philpott]

The Appraising naming strategies here foreground the WWK's interpersonal role and metaphorically narrativise Mairead Philpott's complete subordination to (and abuse by) her husband. Attributing this 'victim' role to her may accurately reflect the state of affairs within her relationship. It also provides an opportunity for the judge to reconcile Mairead Philpott's homicidal actions within ideologically dominant understandings of gender and, more specifically, appropriate submissive femininity. Thus, it is suggested that Philpott became involved in the homicide of her children via her relationship, acting at her husband's behest. In this way, the challenge that her homicidal actions pose to understandings of appropriate 
femininity is - at least-minimised, and - at most-nullified completely. An explanation (at least partial) for her homicidal actions is found in the form of her characterisation as a further 'victim' of her husband's actions.

The other term of Appraisement found within the sentencing remarks is 'monster', which has two instances, both from the case of Dennehy (lines 29 and 30 below). This is the most negatively appraising naming strategy which appears.

29. Kevin Lee's widow describes you as a monster who has taken and ruined her family's lives. [Dennehy]

30. You, Joanne Dennehy, described yourself to Kevin Lee as a monster for what you had done in the past. [Dennehy]

As can be seen from the concordance lines above, the term 'monster' is assigned to Dennehy both by others and herself. In both contexts, this naming strategy locates Dennehy as metaphorically acting in a role. By choosing to include statements where Dennehy is described as monstrous by the widow of one of her victims (line 29), but also where she claims this identity for herself (line 30), the judge creates a narrative that not only de-femininises her, but very clearly de-humanises her as well. This dehumanisation strategy aligns with existing research in relation to WWK, particularly 'bad' homicidal women who are noted as being "demoted from woman to non-woman, to a monster lacking humanity" [54: 205]. They are vilified as an abomination and thus transformed into a mythic, non-human creature. Appraising Dennehy in this way allows the judge to preserve normative patriarchal understandings of appropriate femininity by failing to recognise particularly contemptible acts of female violence as able to be enacted by a human, let alone by a woman. Indeed, by constructing Dennehy as an "inhuman personification of wickedness...the radical implications of her acts are muffled ... at least as far as the dominant purveyors of cultural meaning are concerned. She is returned to her place of passivity and silence" [36: 170].

\section{Summary and Conclusion}

In this analysis, we have exposed a number of interesting naming strategies for WWK, as well as making strides in both linguistic and legal analyses of such cases. As a result of this study, we have come to a number of practical recommendations for the judiciary when writing sentencing remarks. These appear below, following summaries of pertinent findings.

Before considering these recommendations fully, it is important to note that whilst our findings suggest that judicial narratives within sentencing remarks should incorporate a minimalist and neutral description of the facts, we recognise the complex interpretive and ethical dimensions of judicial narrative writing, with competing arguments existing for both 'interpretative' and 'blank' narrative approaches [2]. Indeed, in relation to interpretative narratives, it is arguable that a richer and denser description of facts is beneficial for providing readers with an enriched understanding of the case. We suggest that the strength of such an 
interpretive approach, incorporating in-depth and often personal narratives, can be seen where multiple judges are presenting judgments on a case. As Almog [2: 499] notes, "together, these narratives create the 'marketplace of stories'. Exposure to these competing judicial stories makes it possible to read the judgment in its full context, and thus form a better assessment of it'. However, where only one judge is delivering remarks - as is the case with sentencing remarks - it may not be possible to easily discern the value judgments of the author, with the consequence that these also form part of the 'facts' of the case for some readers. This is particularly relevant in relation to publicly available sentencing remarks, where members of the public may "make up their minds or even change their minds as a result of reading a judgment, and will do by reason of the ... narrative power of the judgment" [2: 495]. As such, and whilst recognising that "even the choice of a highly limited ... narrative ... is, as a matter of fact, interpretive as well as manipulative", [2: 496497], we believe that the recommendations outlined below would positively impact judicial linguistic and narrative choices when writing sentencing remarks.

Pronominal references were (by far) the most common in the corpus. Whereas English does not have a $\mathrm{T}$ versus $\mathrm{V}$ system where power and solidarity may be clearly encoded in pronoun usage, we did find that the proportions of pronouns used was telling. The second-person pronoun was extremely frequent, reflecting both the genre of the corpus and the power flow inscribed in this type of text: the judge talks directly at the offender(s) and makes comments and justifications followed by a final sentence. The use of third-person pronouns can be explained by cohesion patterns in the English language, but also indicates that some consideration may have been taken regarding the 'portability' of the final text, from the court room to the media and wider public who are outside of the immediate social deixis. First-person pronouns were exceedingly uncommon, meaning that women's own narratives were almost never reflected in the discursive artefact, and that their voices were silenced or muted. Nowhere, it seems, were women's narratives of their own lived experiences acknowledged and accepted as voices in their own right.

Recommendation 1: Women's narratives should be directly incorporated into sentencing remarks, in their own words, to allow representation of their lived experiences.

Nomination strategies also showed a clear preference in use; forename? surname was particularly favoured. The frequency of this strategy, in combination with its appearance in a range of grammatical positions, marks it as appropriately distant and the least overtly loaded with power imbalance. By contrast, title? surname was seen to key either social standing (when indicating heteronormative marital status) or the lack thereof (when indicating lack of marital status or a young age). Surname only nomination removed traces of gender identity from the referent, whereas forename only removed social distance and was most often used for victims. When applied to female offenders, forename only indicated subordination and potential victimhood (i.e. at the hands of their intimate male partners).

Recommendation 2: Given the implicit power/solidarity differences in nomination strategies, we recommend that judges should consider moving 
towards standard usage of the most common and least marked form: forename

? surname. This would bring the judiciary more in line with the overall reduction in title usage and remove social marking associated with titles (i.e. Miss, Mrs), which are experienced by female offenders, but not male offenders.

During our analysis of naming strategies of Identification, we discovered that women who kill are often presented in firm relief against 'norm' identities associated with 'appropriate femininity'. They do not behave as mothers 'should' and as girlfriends, they are abandoned. For the women who were wives, adherence to 'appropriate femininity' was clearer where they were passive and deferred to their husbands' views, but this often resulted in them being manipulated and abused. Other identifying features contribute to construction of deviance: women who kill were described as mentally unwell and unable to contribute to society (i.e. through work and other duties).

Within all the sentencing remarks, naming strategies of Functionalisation and Appraisement used for the women were never positive. Homicidal women were never recognised as functionalised members of society. They were not recognised as students, carers, or career women. Rather, the women were recognised as functioning with the parameters of their legal roles or appraised as taking up particularly gendered metaphorical occupations, where they were recognised in dichotomy as degraded victims or dehumanised monsters. We understand that some of these naming strategies (i.e. monster) are likely to be examples of the judges verbatim accepting evidence presented during the trials. Whilst accepting this, and indeed drawing attention throughout this article to extracts where this may be the case, we were ultimately interested in how the judges accepted this evidence and presented it within their sentencing remarks.

Recommendation 3: Judges should consider the impact of identifying and functionalising WWK in their sentencing remarks.

From a corpus linguistic perspective, XML mark-up has proven invaluable in allowing us to nearly instantaneously view, sort, and quantify patterns of naming in the corpus. By allowing the computer programme to 'see' features that are linked semantically or pragmatically, we have increased the frequency of items of interest and gone quite some way to counteract the limitations of using a small, specialised corpus. Rather than searching for single words, lemmata, or fixed strings, we search for groups of reference types. The process of manual mark-up - though somewhat time-consuming - was, in and of itself, extremely rewarding. In corpus linguistics, it is not uncommon to work with corpora of many millions (or indeed, many billions) of words, scraped or otherwise computationally collected. However, in these cases, what is saved in manual compilation is often lost in familiarity. By reading each case multiple times, we were able to identify not only obvious references (pronouns, most combinations of nomination), but also all Categorisation strategies, as well as instances where the identities of women who kill were constructed through Differentiation from 'norm' behaviours. 
We were also able to address one major limitation of corpus linguistic methods, in that it is difficult to identify and describe absences or infrequencies in data. By compiling all naming strategies, we identified infrequencies (notably, of first-person pronouns and physical identification) and associated absences (of the WWK's own voices in legal narratives, linked to muting). The methodology used in this research is one that could be used to examine other areas of law, particularly the legal system's engagement with and construction of women and other 'deviant' social actors. In this way, the full range of naming strategies (both used and disused) and opportunities for voicing (both realised and muted) might be quantified and critically analysed.

However, studies following on in this vein may soon run into the same issue that we have discovered around data availability. At the time being, sentencing remarks are published based on perceived 'public interest', but this is subjective, and does a disservice to individual members of the public who may have their own interest in cases, which are, in any event, matters of public record. Sentencing remarks are routinely removed from the Tribunal and Judiciary's website, and dates for data expiry are not openly communicated. By way of illustration: less than $20 \%$ of the sentencing remarks of cases relevant for our study are accessible. This raises the issue of whether more sentencing remarks should be made publicly and perpetually available (subject to the usual caveats of excluding vulnerable victims or offenders and taboo crimes).

Recommendation 4: Publishing of sentencing remarks should be the rule, rather than the exception.

From a legal research perspective, the use of corpus linguistic tools has allowed us to triangulate, using quantitative evidence to complement and further some of the theoretical work that has already been undertaken in relation to WWK. For example, we have been able to provide, for the first time, frequency analysis in relation to naming strategies of Categorisation, which has formed the basis of much of the existing work in this area (see, for example; $[10,50,53])$. We have also expanded on this work, considering a greater range of potential meanings (i.e. pronominal use and nomination), drawing more explicitly on frameworks more normally associated with linguistics. Analysing sentencing remarks with interdisciplinary, empirical approaches has highlighted the extent to which the judiciary continue to enforce and re-inscribe understandings around 'appropriate femininity' in relation to WWK. Ultimately, the consequence of contact with a patriarchal judicial system is that gendered understandings of women and femininity are repeatedly affirmed. This is not only damaging for the WWK themselves, but for all women, particularly those that come into contact with the criminal justice system.

Acknowledgements We would like to thank our colleagues at Cardiff University School of English, Communication and Philosophy, and Lancaster University Law School for their comments on earlier drafts of this article. 


\section{References}

1. Allen, Hilary. 1987. Justice Unbalanced: Gender, Psychiatry and Judicial Decisions. Milton Keynes: Open University Press.

2. Almog, Shulamit. 2001. As I Read, I Weep: in Praise of Judicial Narrative. Oklahoma City Law Review 26: 471.

3. Ashe, Marie. 1991. The 'Bad Mother' in Law and Literature: A Problem of Representation. Hastings Law Journal 43: 1017-1038.

4. Ballinger, Anette. 2012. A Muted Voice from the Past: The 'Silent Silencing of Ruth Ellis. Social and Legal Studies 21(4): 445-467.

5. Barlow, Charlotte. 2015. Silencing the Other: Gendered Representations of Co-Accused Women Offenders. The Howard Journal of Criminal Justice 54(5): 469-488.

6. Beauvoir, Simone de. 2010. The Second Sex (trans: Constance Borde and Sheila Malovany-Chevallier). London: Random House.

7. Becker, Sarah, and Jill McCorkel. 2011. The Gender of Criminal Opportunity: The Impact of Male Co-Offenders on Women's Crime. Feminist Criminology 6(2): 79-110.

8. Biber, Douglas, Stig Johansson, Geoffrey Leech, Susan Conrad, and Edward Finegan. 1999. Longman Grammar of Spoken and Written English. Harlow: Pearson Education Limited.

9. Boshoff, Anel. 2007. Women as the Subject of (Family) Law. In Choice and Consent: Feminist Engagements with Law and Subjectivity, ed. Rosemary Hunter and Sharon Cowan, 41-57. Oxon: Routledge.

10. Carline, Anna. 2005. Zoorah Shah: An 'Unusual Woman'. Social and Legal Studies 14(2): 215-238.

11. Conley, John, and William M. O’Barr. 1998. Just Words: Law, Language, and Power. Chicago: University of Chicago Press.

12. Coulthard, Malcolm. 1994. On the Use of Corpora in the Analysis of Forensic Texts. The International Journal of Speech Language and the Law 1(1): 27-43.

13. Coulthard, Malcolm, and Janet Cotterill. 2006. Introducing Forensic Linguistics. London: Routledge.

14. Courts and Tribunals Judiciary. Judgments. https://www.judiciary.gov.uk/judgments/. Accessed 30 Dec 2016.

15. Cunningham, Clark. 1992. The Lawyer as Translator, Representation as Text: Towards an Ethnography of Legal Discourse. Cornell Law Review 77: 1298-1387.

16. Easteal, Patricia, Lorana Bartels, Noni Nelson, and Kate Holland. 2015. How are Women Who Kill Portrayed in Newspaper Media? Connections with Social Values and the Legal System. Women's Studies International Forum 51: 31-41.

17. Edwards, Susan. 1984. Women on Trial: A Study of the Female Suspect, Defendant and Offender in the Criminal Law and Criminal Justice System. Manchester: Manchester University Press.

18. Edwards, Susan. 1996. Sex and Gender in the Legal Process. London: Blackstone Press Limited.

19. Habermas, Jürgen. 1977. Erkenntis und Interesse. Frankfurt: Suhrkamp.

20. Halliday, Michael. 1970. Language Structure and Language Function. In New Horizons in Linguistics, ed. John Lyons, 140-165. London: Penguin.

21. Hardie, Andrew. 2014. Modest XML for Corpora: Not a Standard, But a Suggestion. ICAME Journal 38(1): 73-103.

22. Heffer, Chris. 2005. The Language of Jury Trial: A Corpus-Aided Analysis of Legal-Lay Discourse. Basingstoke: Palgrave Macmillan.

23. Henderson, Claire, and Graham Thornicroft. 2009. Stigma and Discrimination in Mental Illness: Time to Change. The Lancet 373(9679): 1928-1930.

24. Hirsch, Susan. 1998. Pronouncing and Persevering: Gender and the Discourses of Disputing in an African Islamic Court. Chicago: University of Chicago Press.

25. Hook, Donald. 1984. First Names and Titles as Solidarity and Power Semantics in English. IRAL 22(3): 183-189.

26. Hunter, Rosemary, Clare McGlynn, and Ericka Rackley. 2010. Feminist Judgments: An Introduction. In Feminist Judgments: From Theory to Practice, ed. Rosemary Hunter, Clare McGlynn, and Erika Rackley, 3-29. Oxford: Hart Publishing.

27. Jackson, Bernard. 1988. Law, Fact and Narrative Coherence. Merseyside: Deborah Charles Publications.

28. Lacey, Nicola. 1998. Unspeakable Subjects: Feminist Essays in Legal and Social Theory. Oxford: Hart Publishing. 
29. Leech, Geoffrey. 1999. The Distribution and Function of Vocatives in American and British English Conversation. In Out of Corpora: Studies in Honour of Stig Johansson, ed. Hilde Hasselga rd and Signe Oksefjell, 107-118. Amsterdam: Rodopi.

30. Lips, Hilary. 2007. Sex and Gender: An Introduction. 6th ed. New York: McGraw-Hill.

31. Matoesian, Gregory. 2001. Law and the Language of Identity: Discourse in the William Kennedy Smith Rape Trial. Oxford: Oxford University Press.

32. McCarthy, Michael, and Anne O'Keefe. 2003. 'What's in a Name?': Vocatives in Casual Conversations and Radio Phone-in Calls. In Corpus Analysis: Language Structure and Language Use, ed. Pepi Leistyna and Charles F. Meyer, 153-185. Amsterdam: Rodopi.

33. McEnery, Tony, and Andrew Hardie. 2011. Corpus Linguistics: Method, theory, Practice. Cambridge: Cambridge University Press.

34. Ministry of Justice. 2014. Freedom of Information Request: FOI 89214 https://www.gov.uk/government/ uploads/system/uploads/attachment_data/file/306601/decision-criteria-to-publish-judgments-rulingssentencing-remarks-on-websites-and-social-media.doc. Accessed 23 June 2017.

35. Morris, Allison, and Ania Wilczynski. 1994. Rocking the Cradle: Mothers Who Kill Their Children. In Moving Targets: Women, Murder and Representation, ed. Helen Birch, 198-217. Berkeley: University of California Press.

36. Morrissey, Belinda. 2003. When Women Kill: Questions of Agency and Subjectivity. London: Routledge.

37. Nicolson, Donald. 1995. Telling Tales: Gender Discrimination, Gender Construction and Battered Women Who Kill. Feminist Legal Studies 3(2): 185-206.

38. Nicolson, Donald. 2000. Criminal Law and Feminism. In Feminist Perspectives on Criminal Law, ed. Donald Nicolson and Lois Bibbings, 1-28. London: Cavendish Publishing.

39. Office for National Statistics (ONS). 2016. Appendix tables: focus on violent crime and sexual offences. Appendix table 2.17a. https://www.ons.gov.uk/peoplepopulationandcommunity/crimeand justice/compendium/focusonviolentcrimeandsexualoffences/yearendingmarch2015/bulletintables focusonviolentcrimeandsexualoffencesyearendingmarch2015 Accessed 23 June 2017.

40. Philips, Susan. 1998. Ideology in the Language of Judges: How Judges Practice Law, Politics, and Courtroom Control. Oxford: Oxford University Press.

41. Potts, Amanda, and Anne Lise Kjær. 2015. Constructing Achievement in the International Criminal Tribunal for the Former Yugoslavia (ICTY): A Corpus-Based Critical Discourse Analysis. International Journal for the Semiotics of Law 29(3): 525-555.

42. Quirk, Randolph, Sidney Greenbaum, Geoffrey Leech, and Jan Svartvik. 1985. A Comprehensive Grammar of the English Language. London: Longman.

43. R v Dennehy, Stretch, Layton and Moore. 2014. Crown Court at Cambridge sitting at the Central Criminal Court. https://www.judiciary.gov.uk/wp-content/uploads/JCO/Documents/Judgments/thequeen-v-dennehy-sentencing-remarks-28022014.pdf. Accessed 18 Aug 2017.

44. R v Hutton and Khan. 2013. Bradford Crown Court. https://www.judiciary.gov.uk/wp-content/ uploads/JCO/Documents/Judgments/r-v-hutton-and-khan-sentencing-remarks?.pdf. Accessed 18 Aug 2017.

45. R v Kunene and Kunene. 2014. Central Criminal Court. https://www.judiciary.gov.uk/wp-content/ uploads/JCO/Documents/Judgments/r-v-nkosiyapha-kunene-and-virginia-kunene-formatted-sentencingremarks.pdf. Accessed 18 Aug 2017.

46. R v Matthews and Hoare. 2015. Bristol Crown Court.

47. Rackley, Ericka. 2010. The Art and Craft Writing Judgments: Notes on the Feminist Judgments Project. In Feminist Judgments: From Theory to Practice, ed. Rosemary Hunter, Clare McGlynn, and Erika Rackley, 44-58. Oxford: Hart Publishing.

48. Roberts, Dorothy. 1993. Motherhood and Crime. Iowa Law Review 79: 99-123.

49. Rock, Frances. 2007. Communicating Rights: The Language of Arrest and Detention. Basingstoke: Palgrave Macmillan.

50. Seal, Lizzie. 2010. Women, Murder and Femininity-Gender Representations of Women Who Kill. Basingstoke: Palgrave Macmillan.

51. Sentencing Guidelines Council. 2004. Overarching Principles: Seriousness. Guidelines. https://www. sentencingcouncil.org.uk/wp-content/uploads/web_seriousness_guideline.pdf. Accessed 23 June 2017.

52. Van Leeuwen, Theo. 2008. Discourse and Practice: New Tools for Critical Discourse Analysis. Oxford: Oxford University Press. 
53. Weare, Siobhan. 2013. 'The Mad', 'The Bad', 'The Victim': Gendered Constructions of Women Who Kill Within the Criminal Justice System. Laws 2(3): 337-361.

54. Weare, Siobhan. 2017. Bad, Mad or Sad? Legal Language, Narratives, and Identity Constructions of Women Who Kill Their Children in England and Wales. International Journal for the Semiotics of Law 30: 201-222.

55. Worrall, Anne. 1990. Offending Women: Female Lawbreakers and the Criminal Justice System. London: Routledge. 